ARTICLE

Received 20 Nov 2016 | Accepted 11 May 2017 | Published 20 Jun 2017

DOI: $10.1057 /$ palcomms.2017.54

\title{
Manipulative uses of pragmatic markers in political discourse
}

Peter Furko ${ }^{1}$

ABSTRACT Pragmatic markers comprise a functional class of linguistic items that do not typically change the propositional meaning of an utterance but are essential for the organization and structuring of discourse, for marking the speaker's attitudes to the proposition being expressed as well as for facilitating processes of pragmatic inferences. Pragmatic marker research has been characterised by descriptive approaches: even case studies that take their data from political discourse tend to focus on linguistic patterns of co-occurrence and sequentiality rather than social-institutional norms or broader societal concerns. The novelty of this article is, therefore, in linking pragmatic marker research, a primarily discourse analytical, language-oriented field to the broader field of Discourse Studies with a focus on manipulative social practices and their manifestations in discursive strategies. This article analyses evidential markers, general extenders, quotation markers and markers of (un)certainty ${ }^{1}$ in political interviews broadcasted by the BBC, CNN and Hungarian ATV. After a short overview of the formal and functional characteristics of pragmatic markers and their relevance to Discourse Studies in general and Critical Discourse Analysis (CDA) research in particular, characteristics of the political interview as political discourse, institutional discourse and media(tised) discourse are discussed. In the second part, the results of previous (primarily descriptive and genre analytical) research are reconsidered from the perspective of CDA and particular pragmatic markers are associated with manifestations of manipulative intent, such as suppression, polarization, recontextualising, conversationalisation and intended ambiguity. An important finding of this study is that a single pragmatic marker can serve several manipulative functions, while a given manipulative strategy is potentially realized by a variety of pragmatic items. Potential manipulative uses are exemplified with a view to applying the heuristic to the analysis of representations of particular political events and happenings, which is a direction for further research.

\footnotetext{
${ }^{1}$ Department of English Linguistics, Karoli Gaspar University of the Reformed Church in Hungary, Budapest, Hungary
} 


\section{Introduction, pragmatic marker research and its relevance to (Critical) Discourse Theory}

- he present article is informed by research in a sub-field of linguistic pragmatics, pragmatic marker research, often considered a "growth industry" (Fraser, 1999: 931) and, at the same time, a "testing ground" (Bordería-Pons, 2008: 1354) for theories of discourse and pragmatics. The article's aim is to, first of all, illustrate that the analysis of pragmatic markers can serve as a methodology for revealing manipulative discursive practices, and, secondly, to demonstrate the benefits of the cross-fertilization between Critical Discourse Analysis and pragmatic marker research.

Pragmatic markers (PrMs) comprise a functional class of linguistic items that do not typically change the propositional meaning of an utterance but are essential for the organization and structuring of discourse, for marking the speaker's attitudes to the proposition being expressed as well as for facilitating processes of pragmatic inferences. A variety of approaches and definitions have been offered, each one informed by a particular theoretical framework (Conversation Analysis, Interactional Sociolinguistics, Rhetorical Structure Theory, Relevance Theory and so on, for an overview cf. Fischer, 2006; Furkó, 2007).

For the purposes of the present paper I define PrMs as a set of syntactically diverse linguistic items (for example, of course, surely, I think, well and so on) that are used for a variety of attitudinal and meta-communicative functions, lack conceptual meaning, and whose distinctive properties include indexicality, context-dependence and multifunctionality. The term PrM will be used as an umbrella term whose extension includes items with a primarily textual, discourse-connecting function as well primarily non-connective, interpersonal attitude markers. The former, textual markers are alternatively referred to as discourse markers (cf. Schiffrin, 1987), connectives or connectors (cf. Celle and Huart, 2007), mots du discours (cf. Ducrot, 1984); the latter, interpersonal markers are alternatively referred to as pragmatic particles (cf. Meyerhoff, 1994), pragmatic expressions (cf. Erman, 1987), pragmatic force modifiers (cf. Nikula, 1996), illocutionary force indicating devices, "IFIDs" (cf. Brown and Levinson, 1987). For a complete overview of the relevant terminological considerations and the functional taxonomy of PrMs; see, for example, Fraser (1996).

Connectives (a subgroup of PrMs, usually discussed in the context of written discourse) have been extensively described as enunciative markers (cf., for example, Ducrot, 1984), while a variety of stance-marking PrMs have also been associated with enunciation and the designation of "elsewhere" in relation to discourse. Angermuller (2014) defines enunciative markers as "the formal traces of enunciation [...] instructing the reader about how the discourse was uttered (Angermuller, 2014: 141) and mentions English I think and French Je crois que as means of positioning practices that mark points of references. AuthierRevuz describes different realizations of I mean as designators of "elsewhere" and as points of heterogeneity in terms of "another word, potential or explicit" in the expression of confirmation of the previous discourse (Authier-Revuz, 2014: 161).

By the same token, the interpersonal markers under scrutiny (evidential markers, general extenders, quotation markers) all display the properties of procedural meaning, indexicality, reflexiveness and polyphony in that by using them, interlocutors reflect on various aspects of the communicative process (be it textual / intertextual relations, presuppositions, sources of information, voices that are represented), and signal such reflections to the (perceived) audience.

As for manipulative use, the presence of enunciative markers in general, and PrMs in particular, carries an increased manipulative potential, because of the very fact that unlike conceptual linguistic items, they are not interpreted but "spontaneously recognized"
(Angermuller, 2014: 60), and instruct the intended audience to focus on how the discourse was uttered, rather than what was uttered. This is confirmed by the observation that meta-linguistic follow-ups are invariably aimed at clarifying conceptual rather than procedural content in the data: typical such utterances include What do you mean by [X], where [X] in the present data is, for example, [limited range / this kind of scrutiny / rotating hosts], or You mean [X]?, for example, You mean [executing him? / he went home?].

The manipulative potential of PrMs, as we will see in the following, is, therefore, realized when the speaker is exploiting or misrepresenting others' voices, manipulating pre-suppositions and mutual assumptions and so on, but is not taken to account by the interlocutor in a follow-up request for clarification.

Unlike enunciative pragmatics, the Anglo-Saxon strand of PrM research has focused on procedural items in oral discourse, mostly in spontaneous everyday conversations and interviews designed to prompt natural speech (cf., for example, Schiffrin, 1987; Schourup, 1999). In recent years, however, there has been a slow increase of interest in the use of PrMs in political discourse. Aijmer and Fetzer (2014) note that there has also been a shift of focus from theoretical studies to usage and corpus-based investigations, as well as variation analyses with special reference to context- and domainspecific functions (Aijmer and Fetzer, 2014: 2).

However, both theoretical and empirical approaches to PrMs have been primarily descriptive and / or discourse analytical (rather than discourse theoretical), critical macro- or microanalyses with ethical or societal preoccupations have been scarce or even non-existent. This is illustrated by the fact that even case studies that take their data from political discourse focus on linguistic patterns of co-occurrence and sequentiality rather than social-institutional norms or broader societal concerns. Zovko (2012), for example, studied the distributional patterns of PrMs in interviews with presidents of Bosnia and Herzegovina and with US presidents. Similarly, Fetzer (2014) examined the distribution of I think, I mean and I believe in political monologues and dialogues with a view to finding co-occurrence patterns among PrMs and other linguistic expressions of modality and evidentiality.

In addition, most of the previous case studies are characterized by a semasiological approach to particular PrMs in English, such as of course (cf. Simon-Vandenbergen, 1992) I think (cf. SimonVandenbergen et al., 2007) or really (cf. Simon-Vandenbergen, 1988), rather than an onomasiological approach to certain subgroups of PrMs such as evidential markers, general extenders, or quotation markers.

Certain PrMs have been considered as contextualization cues and have been analysed from a critical perspective. PrMs as contextualization cues form a subset next to (para)linguistic context-evocative features such as intonation and prosody, lexical choice, code/dialect/style choice and so on. We find sporadic references to lexical items such as of course in Blommaert's (2005: 93), and you know in Gumperz's (1982: 164) work, but these are isolated descriptions of particular occurrences. In this respect I adopt Fetzer's perspective, who thinks that when talking about PrMs as contextualization cues we need to restrict Gumperz's concept of such features to "indexical expressions which are categorized with regard to their micro-contextual references", for example, metacommunicative lexical items with interpersonal, interactional, and sequential functions (Fetzer, 2000a: 1).

\section{Previous micro-analyses of manipulative intent in political discourse}

As we saw above, there is very little CDA-informed research into the functional properties of PrMs in political discourse in general, 
and political news interviews in particular. The majority of CDAinformed micro-analyses tend to focus on the manipulative potential of the choice of content words, that is, conceptual items (for example, Wodak, 1989; van Dijk, 1993) and morpho-syntactic choices such as activation / passivation (van Leeuwen, 1996; Tranchese and Zollo, 2013), nominalization (Fowler et al., 1979; Billig, 2008), the use of pronouns (Bramley, 2001; Irimiea, 2010; Ho, 2013), and the ergative (Stubbs, 1996). As for the study of pragmalinguistic and socio-pragmatic phenomena, there has been an increasing interest in CDA in face management (Armasu, 2013), the realisation of particular speech acts (for example, Hill, 1999; Fetzer, 2007), as well as conversational strategies and topical organization (for example, Greatbatch, 1986; Becker, 2007).

Moreover, Wodak (2007) argues that recent pragmatic theory and methodology "can be fruitfully applied in contemporary CDA research" (Wodak, 2007: 203) and that pragmatic devices are relevant characteristics of hidden and coded discourses (Wodak, 2007: 219). Allott (2005) also suggests that pragmatic features are key to revealing manipulative uses of language (cited in de Saussure, 2007: 183).

In the present paper, a primarily interdisciplinary approach will be taken to the concept of manipulation. Van Dijk (2008) states that the concept is often used in a non-systematic, impressionistic way in CDA, and argues for an approach whereby the social and discursive aspects of manipulation (for example, textuality/intertextuality, interactionality and power abuse) are complemented by a cognitive dimension (van Dijk, 2008: 211).

In cognitive pragmatics, a distinction can be made between informative and manipulative communication on the basis of the intentions assigned to the speaker and the ability of the hearer to recognize such intentions (cf. Németh, 2014: 475). Manipulative communication is successful if the hearer recognizes the speaker's informative and communicative intentions, but fails to recognize the speaker's influencing intention. However, speakers' intentions, especially manipulative intentions, are very difficult to identify for researchers, even if all the linguistic (conceptual and textual) and non-linguistic (contextual) clues, whether explicitly or implicitly conveyed, are taken into consideration (cf. Németh, 2014: 472).

Even though we can safely assume a global manipulative intent on the part of interviewees (and interviewers) in political interviews (cf. Section "The political news interview as a genre" below), I will be using the distribution and co-occurrence patterns of pragmatic markers in the "pre-genre" (cf. Swales, 1990: 58) of everyday conversations as frames-of-reference with a view to making safer assumptions about local manipulative intentions in mediatised political discourse.

\section{The political news interview as a genre}

The political interview is a genre that is best understood in terms of its formal-functional characteristics as institutional talk (cf. Heritage and Greatbatch, 1991), political discourse, media discourse and mediatised discourse. As for the first of these components, the institutional setting in which political interviews are produced clearly delineate the participants' roles, functions and underlying purposes / motivations (cf. Clayman and Heritage, 2004: 37). The interviewer's (IR's) role is to represent a media organization (in our case, the BBC, CNN and ATV) with its specific guidelines for impartiality, accuracy, integrity and so on, while the interviewee (IE) represents a political organization (government, political party, civil society and so on) with a clear intent to propagate the organization's concepts, activities, messages, slogans and so on. McNair observes that there is a relationship of "mutual convenience and interdependence" (McNair, 2011: 25) between IRs and IEs, in that IEs strive to satisfy IRs' hunger for news while maximising their own favorable public exposure (ibid.).
Political discourse has also been defined in terms of a variety of general issues such as power, conflict, control, and domination (cf. Wilson, 2001). Different types of political discourse are best seen as graded along different contextual dimensions such as participants, topics, formality, as well as goals and purposes. Wilson's (1993) study, for example, focuses on a peripheral type of political discourse, namely personal narratives on political themes but told by politically powerless actors. Mediatised political interviews and their subtypes (e.g. news interviews and celebrity interviews) constitute more close-to-the core political discourse in terms of the topics, participants as well as the setting (media discourse being the "extended arm of political discourse", cf. Dedaic, 2005: 673). With regard to the hybridity, gradedness and fuzziness of political discourse, Wodak observes that "many boundaries have become blurred: the boundaries between entertainment and news, between politicians and celebrities, and so forth" (Wodak, 2009: xiv). As the following analysis will reveal, the conversationalisation of mediatised political discourse is yet another sign of the blurred boundary between the public and the personal domain, and it is, by itself a manifestation of manipulative intent on the part of political actors.

The mediatisation of political interviews also entails that two different frames of interaction occur simultaneously: the first-frame interaction is between the IR(s) and the $\operatorname{IE}(\mathrm{s})$, while there is a second-frame interaction between the first-frame participants and the audience, either present in the studio or in front of their television sets (cf., for example, Fetzer, 2000b). As a result, the IR, supposedly, acts as an animator, rather than the source of the whole spectrum of public opinion, while the IEs' aim is to animate the views, beliefs, decisions, actions, and so on, of the organization the IE represents and to influence the overhearing audience, rather than the IR, even though it is the IR whom s/he is engaged in face-to-face conversation with.

From a structural perspective, political interviews are dyadic by nature with a very specific turn-taking mechanism and set of constraints. There is an asymmetrical relationship between the IR and the IE in that the former invariably produces the first-pair part (cf. Schegloff, 1972) of adjacency pairs (usually a question prefaced or followed by a comment), selects the IE as the next speaker, who produces the second-pair part (an answer / reaction to the IR's question or comment). Because of the genre-specific conventions of political interviews as well as a set of expectations on the part of the audience, the content of the IE's turns always have to, at least, appear relevant to the IR's first-pair part, if, however, the IE's second-pair part is irrelevant, it is duly noted and / or made explicit by the IR, which is markedly different from the exchange mechanics of other discourse genres such as those of naturally-occurring conversations.

\section{Data and methodology}

The study is based on both English and Hungarian corpora of political interviews and consequent online comments. The English corpus consists of two subcorpora: a BBC subcorpus and a CNN subcorpus. The former consists of 37 transcripts of political news interviews such as Hardtalk, Question Time and Newsnight that vary in length between 30 and $60 \mathrm{~min}$. The transcripts comprise a total of 79,225 words $\pm 2 \%$, allowing for technical / transcript-specific information such as the indication of participants' names.

The CNN subcorpus comprises 36 transcripts of Larry King Live. Each interview lasts approximately $50 \mathrm{~min}$, the total word count $(80,436 \pm 2 \%)$ of the CNN subcorpus thus makes it comparable to the BBC subcorpus.

The analyses of Hungarian PrMs have been carried out on a corpus comprising two types of political discourse: 
- a collection of seven formal/confrontational evening political interviews, Egyenes beszéd (Straight talk) broadcasted on ATV (each of them last for approximately $60 \mathrm{~min}$ and feature one constant IR and seven different IEs),

- chatroom discussions of current political themes, available at www.atv.hu

The Hungarian corpus was also compiled with a view to being comparable in size to the other two corpora.

The present paper builds on the findings of previous research into the functional spectrum of PrMs in the above corpora of political discourse (cf. Furkó, 2013; Furkó and Abuczki, 2014; Furkó et al., forthcoming), and reconsiders those findings from the perspective of influencing intentions in general and manipulative intent in particular. The aim is to associate different groups of PrMs (evidential markers, general extenders, quotation markers and so on) with particular manifestations of manipulative intent identified in the relevant CDA research, such as suppression, polarization, recontextualising and conversationalisation. It is important to point out that a single PrM can serve several manipulative functions, while a manipulative strategy might be realized by a variety of pragmatic items. Consequently an onomasiological approach to the functional spectrum of a set of PrMs is vindicated.

\section{PrMs marking manipulative intent in political interviews} Evidential markers: suppression and backgrounding. Evidential markers (EMs) constitute a subclass of pragmatic markers that are alternatively defined as PrMs that "signal the degree of confidence, positive or negative, weakly or strongly, held by the speaker about the truth of the basic message" (Fraser, 1996: 167), and as PrMs that "indicate a speaker's attitude regarding the validity of certain information, for example, whether it is certain, probable, or untrustworthy" (Nuckolls, 1993: 235). In addition to marking the source and the reliability of information and knowledge (Ifantidou, 2001: 3), they may also indicate how knowledge or information was acquired, for example, through personal experience, inference, or report (Nuckolls, 1993: 235).

The most salient EM is of course in spontaneous everyday conversations (cf. Holmes, 1988; Lewis, 2006), confrontational news interviews (based on the BBC corpus) as well as in celebrity interviews (based on the $\mathrm{CNN}$ corpus). In celebrity interviews, similarly to spontaneous conversations, of course can express strong agreement with the interlocutor's previous utterance ('emphatic yes' function, cf. Lewis, 2006), while in other contexts it marks topic shifts, evaluations in narratives as well as the end of a list (for example, "Condoleezza Rice the national security advisor, Mary Madeline and of course, me", CNN Larry King Live). However, in political news interviews the range of functions of course fulfils is markedly different from its use in the other two discourse types. A mere 16 out of 85 tokens of of course in the BBC corpus are interactional, the remaining occurrences can be grouped into two categories: (1) they are either used in anticipation of an opposing viewpoint, and/or the audience's objections (heteroglossic uses, cf. Bakhtin, 1987), or (2) they background propositions that were previously foregrounded by the previous speaker:

(1) IE: No I actually am more interested in not having a whole lot of time wasted for police and courts, as well as victims, with people uselessly maintaining their innocence. Some of them of course will get away with it 'cos they'll find a jury that believes what they say. I'm more interested if people are guilty that they show a bit of contrition, stop making things worse and admit straight away. (BBC5 Live, 18 May 2011, emphasis is mine)
(2) IR: Do you ... If you were in No. 10 at the moment and Nissan came to you, the other carmakers came to you and said, "We've done a very, very good job for this country. We've created a lot of employment. We need some help in the short-term", what would you tell them?

IE: Of course I want to help. But let's take Nissan because what ... (BBC's The Andrew Marr Show, 11 January 2009, emphasis is mine)

As for the heteroglossic function of of course, SimonVandenbergen et al. conclude that of course confirms solidarity with the like-minded, construes solidarity with those who need to be persuaded, and, at the same time contributes to the image of the speaker being "in the know", thus giving the speaker "a temporary advantage in the battle for scoring with the audience" (Simon-Vandenbergen et al., 2007: 66). In other words, IEs exploit the multifunctionality of of course by influencing the assumptions of different segments of the audience simultaneously, addressing a range of alternative viewpoints about particular political themes.

The backgrounding uses of EMs, on the other hand, relate to the manipulative strategies of suppression and selective presentation. By shifting attention away from themes that are not congruent with their own beliefs and ideological aims, political actors can continue to pursue their own agenda. From a cognitive pragmatic perspective (cf. Sperber and Wilson, 2002), what the politician does is highlight elements of the mutual cognitive environment that, if appropriately combined, will lead the audience to the conclusions that the politician wants them to arrive at. The backgrounding uses of EMs are, therefore, inherently manipulative in political news interviews, and the subtlety of the manipulation lies in the way politicians "construct a socially, politically and ideologically skewed reality" (that is, mutual cognitive environment) rather than "deconstruct an existing objective reality" (Connel, 1980, cited in Tranchese and Zollo, 2013: 157).

Despite the fact that we find similar patterns of EM-use in celebrity interviews and spontaneous conversational data in terms of response marking and other interactional functions, manipulative use is more salient in the former: one manifestation is the frequent co-occurrence of EMs and vocatives, as in (3) and (4):

(3) IE: You have to remember, of course, Larry, that the people in this country have spent decades under a repressive political regime, and also under a command economy, where they were told what they must do (Larry King Live, 19 March 2004, emphasis is mine).

(4) IR: What's the status of the investigation, Ted, to this minute?

IE: Well, it's ongoing. And the big question of course, Larry, is still why? (Larry King Live, 6 November 2009, emphasis is mine)

The EM surely also shows different patterns of use across the three discourse types. Downing (2009) observes that this EM has negative connotations for speakers of British English:

(5) At a recent conference in Spain during which I read a paper on the historical evolution of surely, question time produced an immediate comment from a young British delegate sitting in the front row. It was as follows: "I don't like people who use surely; they make themselves superior to you. When I was at school, the headmaster used to stand 
by my desk looking down at me and would say 'Surely you can do better that that!'” (Downing, 2009: 79, emphasis is mine).

Moreover, corpus-based research shows that people in control in general, and people asking questions in particular are more likely to use surely than the powerless or interlocutors answering questions (Downing, 2009: 91). In the BBC corpus, however, interviewees are as likely to use surely as interviewers:

(6) IE: But surely, the important thing in relation to Iraq is no matter what people's feelings are about what happened there, is that we've got to move on now. (BBC Politics Show, 13 June 2004, emphasis is mine)

Evidential markers are used manipulatively in the Hungarian data as well. In (7), for example, the speaker is a politician who criticizes the activity of the government and uses the Hungarian PrM ugye ( "isn't it so") for presupposition manipulations, taking for granted that it is the mistakes 'they' have made that have resulted in the recession 'we' have to suffer at present. Presupposition manipulation is thus combined with a polarisation between the in-group ("us", implying people who are dissatisfied with the government's incompetence) and the outgroup ("them" implying the government and its supporters):

(7) IE:...az összes hiba, amit elkövettek, mindaz ami ugye recesszióba sodorta a gazdaságot 'all the mistakes they've made, all the things that have $D M^{\text {ugye }}$ lead the economy into recession' (ATV Egyenes Beszéd 27 December 2011, emphasis is mine).

General extenders: playing down the importance of alternative viewpoints. General extenders (GEs) comprise a subset of pragmatic markers that usually occur in utterance final position and have the basic form of conjunctive (and) or disjunctive (or) plus noun phrase, for example, and stuff (like that), and the like, and whatnot, and so on, et cetera. They have been alternatively called "set marking tags" (for example, Stubbe and Holmes, 1995), "vague category identifiers" (for example, Channel, 1994), "list completers" (for example, Lerner, 1994), and "discourse extenders" (for example, Norrby and Winter, 2002). The different terms mark different aspects of GEs' formal properties and functions: GEs usually appear at the end of lists, and thus indicate additional members of a list, and/or imply the fact that there is a set or category which is exemplified by the items preceding them.

In political discourse, there are two ways in which GEs are used manipulatively, firstly, they might imply that there is more to be said on a certain issue than the speaker has time to say in the interview. In (8), for example, the IE implies that there are several more pieces of evidence for the economic stability of Iraq, even though he only gives a single (and controversial) example:

(8) IE:... there's a clear political path for the Iraqis to follow and there are important developments on the economic side as well. There's a new a stable currency and so on. (Politics Show, Sunday 27 June 2004, emphasis is mine)

Alternatively, GEs can be used to downplay alternative viewpoints and policies and thus, similarly to evidential markers, provide ways of manipulating the mutual cognitive environment shared by the first-frame and second-frame participants in the interview (notice the co-occurrence of a GE and an EM in 10):
(9) IE:... this idea that you can just ram through and use the Salisbury Convention and so on and so forth, where identity cards are concerned and the House of Lords is involved, I think it would be a great mistake from the Prime Minister's point of view (Politics Show, Sunday 13 November 2005, emphasis is mine).

(10) IE: It's all very well to talk about statistics of number of people having successful operations and so on, but you shouldn't have to do that in a modern health service surely (Newsnight 7 February 2003, emphasis is mine).

(11) Lehet itt mézes mázosan beszélni meg minden! Mindenki tartsa el magát! Termeljen!!

One could talk smoothly, beat about the bush $G E^{\text {meg minden }}$ [implicature: what's the point?]! Everyone should support themselves and be productive! (data from a Hungarian political chatroom, emphasis is mine).

The role of quotation markers in decontextualising and recontextualising texts, legitimising opinions and polarising the audience. Tranchese and Zollo (2013) observe that the selection and organization (representation) of particular voices and viewpoints is ideologically significant in media discourse (Tranchese and Zollo, 2013: 156). They approach voicing from the perspective of intertextuality and argue that to decontextualise and recontextualise a text is an act of control, in that attributed intertextuality can either convey authority and legitimation, or a challenge to the voice that is being quoted or represented (ibid.). Lauerbach (2006) approaches voicing from the perspective of Goffman's theory of social interaction and defines it as represented discourse in which "a figure other than the speaker is being animated without the speaker being understood to be either the author of the words or to be responsible for them" (Lauerbach, 2006: 199). She also makes a distinction between voicing and ventriloquizing, the latter of which is defined as "putting one's own words into the mouths of others" (ibid.).

From a cognitive pragmatic perspective voicing and ventriloquizing can both be described as echoic uses. In relevance theory (cf. Sperber and Wilson, 2002) every utterance is an interpretation of the thought that the speaker wishes to communicate. However, a thought is a representation too, and as such it might be presented as a description of a state of affairs or as an interpretation of a thought attributed to someone else (or oneself at another time). In the case of echoic uses of language, "the speaker's utterance will be understood as an interpretation of a thought which is itself an interpretation of an attributed thought" (Blakemore and Gallai, 2014: 111). The relevance of echoic utterances lies in the speaker's attitude towards the represented thought, which can be one of association or dissociation. In the corpora based on political news interviews attributed thoughts that speakers distance themselves from are usually introduced by the PrM oh, while association is conveyed by prefacing ventriloquized utterances by well:

(12) IE: It's rather an odd situation we have here where the, the government are trying to legislate, or the House of Commons is trying to legislate very very quickly, that this is a bill that passed all its stages in the House of Commons, minimum of debate in one day, and then they say, $\boldsymbol{o h}$ it doesn't need to come in to effect for eighteen months or two years. (BBC's Politics Show, 10 October 2004, emphasis is mine)

(13) IE: over the past 18 months, the eurozone governments have rather let us down, given us, you know, 
wonderful hope on the basis of the thrust of what they've been saying and then we've seen the fine print we've thought, "well, actually, there's rather less to all of this than we hoped.” (BBC Radio 4 Today Programme, 6 September 2011, emphasis is mine)

It is interesting to consider that, once again, association and dissociation are reinforced by the polarization between 'they' and 'we': the ironic/mocking use of oh co-occurs with they in the enquoting utterance of (12), while the associative use of well cooccurs with we in (13).

If we compare the distribution of different types of reporting in political interviews with other types of discourse, the manipulative potential of voicing and the accompanying PrMs becomes apparent. Figure 1 is adopted from research into the frequency of direct, indirect reporting and voicing across four genres (cf. Furkó et al., forthcoming):

The figure shows that voicing is more frequent in MPIs than in any other genres, even though it has been previously identified as a characteristic of spontaneous, everyday, casual conversations. This could be explained by that fact that, unlike in indirect and direct reports, in the case of voicing there is no expectation that the exact / approximate proposition has actually been put forward, thus, this type of reporting lends itself to manipulative uses in political discourse.

In the Hungarian corpus, the PrM a (whose source category is that of interjection) has a similar echoic function, and often introduces ironic representations of attributed thoughts:

(14) Orbán Viktor kijelentette, hogy ő még sohasem hazudott. "Viktor Orbán has stated that he has never lied". Á dehogy, csak minden kampányban. "PrM $\boldsymbol{M}^{a}$ sure he hasn't, he only lies in his political campaigns" (www.atv.hu, emphasis is mine).

Other manifestations of manipulation: conversationalisation and the exploitation of ambiguity. In addition to revealing local manipulative intent, that is, hidden influencing intent marked by particular tokens of PrMs in particular contexts, quantitative data on the use of PrMs can also reveal global manipulative intent, that is, influencing intent reflected by the frequency and distribution of PrMs in political interviews. One such manipulative intent is the conversationalisation of mediatised political discourse. This tendency has been noticed by several researchers. Fetzer and Weizman (2006), for example, state that "politics has undergone dramatic changes [in that] the primarily monologue-oriented mode of discourse, which prevailed in the fifties, sixties, seventies and eighties, is no longer considered to be appropriate in the western and Anglo-American contexts" (Fetzer and Weizman,
2006: 146). Sandova (2010) observes that politicians use conversational style in an effort to impress their audience, and to be able to influence them more easily. Fairclough (1995) argues that conversationalisation is a type of marketization of ideologies and has a specific (hidden) consensus-building effect (Fairclough, 1995: 51).

Through the analysis of the use of selected PrMs we can supplement previous (mainly qualitative) research on conversationalisation with a quantitative approach, since conversationalisation is reflected by the high incidence as well as the D-value of a number of PrMs in political interviews. D-value or " $\mathrm{D}$-function ratio" (cf. Stenström, 1990) describes the categorial multifunctionality of PrMs. An individual PrM's D-value is calculated as a quotient of the number of tokens of a PrM that fulfil discoursepragmatic functions and the total number of occurrences in a given discourse. Since the PrMs under scrutiny are markers of orality, the higher their $\mathrm{D}$-value, the more similar the interview sounds to spontaneous, informal, face-to-face conversations.

The incidence of I mean is 13 tokens per ten thousand words (tpttw) in the BBC corpus, 12 tpttw in the CNN corpus and 23 tpttw in spontaneous conversations (Juilland's $\mathrm{D}=0.78$, Variation Coefficient $=0.31 / 21.95 \%)$. Its D-value of $79 \%$ is even closer to that in conversational corpora, such as the London-Lund Corpus of Spoken English. Moreover, the occurrence of of course in celebrity interviews exceeds its incidence in spontaneous conversations (2.8 tpttw vs. 1.9 tpttw, Juilland's $\mathrm{D}=0.97$, $\mathrm{CV}=0.03 / 2.56 \%$ ), while the $\mathrm{D}$-value of well in both news interviews and celebrity interviews comes very close to its $\mathrm{D}$-value in naturally-occurring conversations $(81.6 \%, 85.7 \%$ and $84 \%$ / $83 \%$, respectively). This means that, with respect to these indicators of orality, there are no statistically significant differences between the two subcorpora $\left(\chi^{2}=1.3717, p>0.05\right)$; between the CNN subcorpus and a random sample of 80.000 words of the Santa Barbara Corpus of American English as a reference corpus $\left(\chi^{2}=0.4286, p>0.05\right)$; and between the BBC corpus and the London Lund Corpus, used as a reference corpus of British English $\left(\chi^{2}=0.5167, p>0.05\right)$.

Yet another global manipulative intent is manifested in the exploitation of the ambiguity of PrMs in political discourse. It is commonly observed in the literature that I think is the most notoriously ambiguous PrM (cf. Aijmer, 1997), and, as it happens, it is the most frequently used PrM in the BBC corpus (50 tpttw as opposed to the $26 \mathrm{tpttw}$ in the non-surreptitious conversations of the LLC, Juilland's $\mathrm{D}=0.68, \mathrm{CV}=0.32 / 31.58 \%$ ). Holmes, for example, identified "two distinct and contrastive [core] functions of I think" (Holmes, 1990: 199), expressing either uncertainty or certainty. Thus I think can function as a booster or a downgrader, it can make a point specific / emphatic or backgrounded, it can express involvement or detachment.

The distribution of the types of reporting

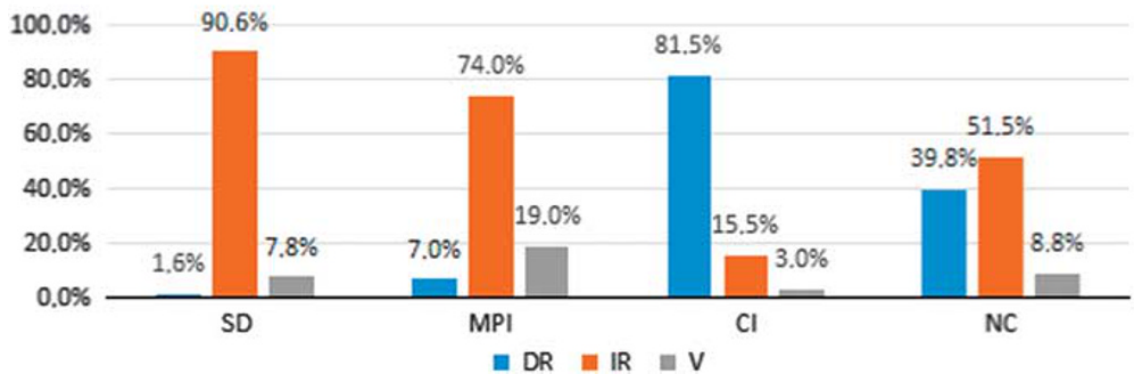

Figure 1 | Types of reporting across four genres: scripted discourse (SD), mediatized political interviews (MPI), celebrity interviews (CI) and natural conversation (NC), adapted from Furkó et al., (forthcoming). 
In the $\mathrm{BBC}$ corpus there are several cases where the ambiguity cannot be resolved with reference to either suprasegmental features (intonation, stress, and pitch) or co-occurrence patterns with modal verbs and adverbs (cf. Fetzer, 2014). As a result, the data suggests that $I$ think is used strategically and the ambiguity between emphasis and backgrounding, certainty and uncertainty, subjectivity and stance taking is often intentional. The probability of manipulative intent is further increased if we consider that there are social class differences in terms of the use of particular PrMs. Huspek (1989) suggests that I think has different functions and interpretations for working-class speakers and power-holding speakers: while it marks certainty for middle-class speakers, it marks solidarity among members of the working class (Huspek, 1989 cited in Aijmer and SimonVandenbergen, 2009: 15). By using I think, therefore, politicians can appeal (or so they might believe) to the rationality of the middle class listeners and the solidarity of the working class audience, at the same time.

\section{Conclusions, directions for further research}

Because of its inherently semasiological nature, pragmatic marker research has been characterised by microanalyses and bottom-up approaches to a variety of discourse-pragmatic phenomena. However, if PrM research is informed by CDA, an inherently topdown approach preoccupied with ethical and societal concerns (cf. Angermuller, 2014: 11), we can gain new insights into distributional patterns that were previously unnoticed. The genrebased analysis of political news interviews and celebrity interviews (cf. Furkó, 2013; Furkó and Abuczki, 2014) revealed that the functional spectrum of PrMs in celebrity interviews is in many ways similar to that in spontaneous informal conversations, while PrMs fulfil fewer interactional and more heteroglossic functions in more prototypical political news interviews. However, on the basis of the analysis of manipulative uses, we can make further refinements to the distributional patterns of PrMs. As we saw above, celebrity interviews are markedly different from spontaneous face-to-face conversations in that manipulative uses are as salient in celebrity interviews as in close-to-the-core political news interviews. These tendencies were revealed after we looked at co-occurrence patterns with pronominal choices and vocatives, both of which have been extensively studied as manipulative in the relevant $\mathrm{CDA}$ literature.

Conversely, PrM research has much to offer in informing CDA analyses and can either reinforce observations made on the basis of other lexical and morpho-syntactic choices or reveal new discursive strategies of control and dominance through quantitative analyses of functional distributions, D-values and cooccurrence patterns. Wodak and Meyer (2009) observes that "CDA researchers very rarely work with interactional texts such as dialogues" (Wodak and Meyer, 2009: 10), a tendency which seems to have changed in recent years (cf. e.g. Wodak, 2009; Mölder, 2010; Kantara, 2012). The analysis of interactional texts, therefore, requires a new toolbox, to which PrM research can provide a useful addition.

A promising direction for further research is the analysis of PrMs' use from a multimodal perspective. A pilot study (cf. Abuczki and Furkó, 2015) suggests that there are correlations between particular PrM functions and the non-verbal signs (facial expressions, eyebrow movement, hand gestures and so on) communicators make while, or immediately beforeuttering PrMs. Multimodality has long been a focus of CDA research, thus, a critically informed, multimodal analysis of $\operatorname{PrM}$ uses in political interviews might reveal even more "traces of the punctuation of the unconscious" (Angermuller, 2014: 158) as well as influencing or manipulative intent.

\section{Notes}

1 These terms will be clarified in the Section "PrMs marking manipulative intent in political interviews" of the article.

2 By a neutral pre-genre Swales means everyday, spontaneous conversations where manipulative intent is not presumed.

\section{References}

Abuczki Á and Furkó BP (2015) Towards the construction of a decision tree for the functional disambiguation of Hungarian DSDs. poster presented at TextLink: Structuring Discourse in Multilingual Europe, First Action Conference. 25-28 January 2015, Louvain-la-Neuve, Belgium.

Aijmer K (1997) I think-An english modal particle. In: Swan T and Westvik OJ (eds). Modality in Germanic Languages. Historical and Comparative Perspective. Mouton de Gruyter: Berlin, Germany/New York, pp 1-47.

Aijmer K and Fetzer A (2014) Discourse linguistics - Theory and practice. Functions of Language; 21 (1): 1-5.

Aijmer K, Simon-Vandenbergen A (2009) Pragmatic markers. In: Östman J and Verschueren J (eds). Handbook of Pragmatics: 2009 Installment. John Benjamins: Amsterdam, The Netherlands, pp 1-29.

Allott N (2005) The role of misused concepts in manufacturing consent: A cognitive account. In: deSaussure L and Schulz P (eds). Manipulation and Ideologies in the Twentieth Century. John Benjamins: Amsterdam, the Netherlands, pp 147-168.

Angermuller J (2014) Post-structuralist Discourse Analysis - Subjectivity in Enunciative Pragmatics. Palgrave Macmillan: Basingstoke, Houndmills, UK.

Armasu VD (2013) The Concept of Politeness in Everyday and Professional Discourse. PhD dissertation, Babes-Bolyai University. http://193.231.20.119/ doctorat/teza/fisier/1427, accessed 15 January 2016.

Authier-Revuz J (1984/2014) Hétérogénéité(s) énonciative(s). (Enunciative heterogeneities) Langages 73: 98-111. In: Angermuller J, Maingueneau D and Wodak $\mathrm{R}$ (eds). The Discourse Studies Reader - Main Currents in Theory and Analysis. John Benjamins: Amsterdam, The Netherlands/Philadelphia, PA, pp 155-165.

Bakhtin M (1987) The Dialogic Imagination: 4 Essays. University of Texas Press: Austin. Becker A (2007) Are you saying...? A cross-cultural analysis of interviewing practices in TV election night coverages. In: Fetzer A and Lauerbach GE (eds). Political discourse in the media. John Benjamins: Amsterdam, The Netherlands, pp 139-162.

Billig M (2008) The language of critical discourse analysis: The case of nominalization. Discourse \& Society; 19 (6): 783-800.

Blakemore D and Gallai F (2014) Discourse markers in free indirect style and interpreting. Journal of Pragmatics; 60, 106-120.

Blommaert J (2005) Discourse - A Critical Introduction. Cambridge University Press: Cambridge, NY.

Bordería-Pons S (2008) Introduction to the special issue on empirical data and pragmatic theory. Journal of Pragmatics; 40 (8): 1353-1356.

Bramley NR (2001) Pronouns of Politics: the use of pronouns in the construction of 'self' and 'other' in political interviews. PhD dissertation, Australian National University. https://digitalcollections.anu.edu.au/bitstream/1885/46225/5/01front. pdf, accessed 10 August 2016.

Brown P and Levinson SC (1987) Politeness. Some Universals in Language Usage. Cambridge University Press: Cambridge, UK.

Celle A and Huart R (eds) (2007) Connectives as Discourse Landmarks. Benjamins: Amsterdam.

Channel J (1994) Vague Language. Oxford University Press: Oxford.

Clayman S and Heritage J (2004) The News Interview-Journalists and Public Figures on the Air. Cambridge University Press: Cambridge, UK.

Connel I (1980) Television news and social contrast. In: Hall S, Hobson D, Lowe A and Willis P (eds). Culture, Media, Language: Working Papers in Cultural Studies. Hutchinson: London, pp 139-156.

Dedaic MN (2005) Ironic denial: Toboze in Croatian political discourse. Journal of Pragmatics; 37 (5): 667-683.

de Saussure L (2007) Pragmatic issues in discourse analysis. Critical Approaches to Discourse Analysis Across Disciplines; 1 (1): 179-195.

Downing A (2009) Surely as a marker of dominance and entitlement in the crime fiction of P. D. James. Brno Studies in English; 35 (2): 79-92.

Ducrot O (1984) Le dire et le dit. Minuit: Paris.

Erman B (1987) Pragmatic Expressions in English: A Study of "You Know", "You See" and "I Mean" in Face-to-Face Conversation. Almqvist \& Wiksell International: Stockholm, Sweden.

Fairclough N (1995) Media Discourse. Edward Arnold: London.

Fetzer A (2000a) Contextualization cues: More- and less-fuzzy hedges, discourse markers and interpersonal markers. Discourse Particles, Modal and Focal Particles and all that stuff ... An International Conference on Particles. Linguistic Society of Belgium: Brussels.

Fetzer A (2000b) Negotiating validity claims in political interviews. Text; 20 (4): 1-46. Fetzer A (2007) Challenges in political interviews: An intercultural analysis. In Fetzer A and Lauerbach GE (eds). Political Discourse in the Media. John Benjamins: Amsterdam, The Netherlands, pp 163-192. 
Fetzer A (2014) I think, I mean and I believe in political discourse: Collocates, functions and distribution. Functions of Language; 21 (1): 67-94.

Fetzer A and Weizman E (2006) Political discourse as mediated and public discourse. Journal of Pragmatics; 38 (2): 143-153.

Fischer K (ed) (2006) Approaches to Discourse Particles. Elsevier: Oxford.

Fowler R, Hodge B, Kress G and Trew T (1979) Language and Social Control. Routledge: London.

Fraser B (1996) Pragmatic markers. Pragmatics; 6 (2): 167-190.

Fraser B (1999) What are discourse markers? Journal of Pragmatics; 31 (7): 931-952.

Furkó BP (2007) The Pragmatic Marker -Discourse Marker Dichotomy Reconsidered: The Case of 'Well' and 'Of Course'. Debrecen University Press: Debrecen, Hungary.

Furkó BP (2013) The functional spectrum of pragmatic markers in political news interviews and celebrity interviews. Topics in Linguistics; 11, 13-21.

Furkó BP and Abuczki Á (2014) English discourse markers in mediatised political interviews. Brno Studies in English; 40 (1): 45-64.

Furkó BP, Kertész A and Abuczki Â (forthcoming) Discourse markers in different types of reporting. In: Capone A (ed). Indirect Reports - Perspectives in Pragmatics, Philosophy and Psychology. Springer Verlag: Heidelberg, Germany.

Greatbatch D (1986) Aspects of topical organisation in news interviews: The use of agenda-shifting procedures by interviewees. Media, Culture and Society; 8 (4): 441-455.

Gumperz J (1982) Discourse Strategies. Cambridge University Press: Cambridge, UK.

Heritage J and Greatbatch D (1991) On the institutional character of institutional talk: The case of news interviews. In: Deirdre B and Zimmermann DH (eds). Talk and Social Structure: Studies in Ethnomethodology and Conversation Analysis. University of California Press: Berkley, CA, pp 93-137.

Hill JH (1999) Read my article: Ideological complexity and the overdetermination of promising in American presidential politics. In: Kroskrity PV (ed). Regimes of Language: Ideologies, Polities, and Identities. School of American Research Press: Santa Fe, NM, pp 259-291.

Ho V (2013) Strategic use of nouns and pronouns in public discourse: The case of the fine-tuning of the medium of instruction policy in Hong Kong. Pragmatics; 23 (1): 51-67.

Holmes J (1988) Of course: A pragmatic particle in New Zealand women's and men's speech. Australian Journal of Linguistics; 2, 49-74.

Holmes J (1990) Hedges and boosters in women's and men's speech. Language and Communication; 10 (3): 185-205.

Huspek M (1989) Linguistic variability and power: An analysis of you know/I think variation in working-class speech. Journal of Pragmatics; 13, 661-683.

Ifantidou E (2001) Evidentials and Relevance. John Benjamins: Amsterdam, The Netherlands/Philadelphia, CA.

Irimiea S (2010) Rhetorical and comparative study of the victory speeches of Barack Obama and Mircea Geoana. JoLIE; 3, 41-53.

Kantara A (2012) Adversarial challenges and responses in greek political interviews: A Case Study. Critical Approaches to Discourse Analysis across Disciplines; 5 (2): 171-189.

Lauerbach G (2006) Discourse representation in political interviews: The construction of identities and relations through voicing and ventriloquizing. Journal of Pragmatics; 38 (2): 196-215.

Lerner GH (1994) Responsive list construction. Language and Social Psychology; 13 (1): 20-33.

Lewis D (2006) Discourse markers in english: A Discourse-pragmatic view. In: Fischer K (ed). Approaches to Discourse Particles. Elsevier: Amsterdam, The Netherlands, pp 43-59.

McNair B (2011) An Introduction to Political Communication. Routledge: London.

Meyerhoff M (1994) Sounds pretty ethnic, eh?: A pragmatic particle in New Zealand English. Language in Society; 23 (3): 367-388.

Mölder M (2010) Meanings of democracy in Estonia: An analysis of focus group discussions. Critical Approaches to Discourse Analysis across Disciplines; 4 (1): 38-53.

Németh TE (2014) Implicit arguments at the grammar-pragmatics interface: Some methodological considerations. Argumentum; 10, 679-694.

Nikula T (1996) Pragmatic Force Modifiers. A Study in Interlanguage Pragmatics. University of Jyvaskyla: Jyvaskyla.

Norrby C and Winter J (2002) Affiliation in adolescents' use of discourse extenders. Proceedings of the 2001 conference of the Australian Linguistic Society. http:// www.als.asn.au/proceedings/als2001/winter_norrby.pdf, accessed 15 January 2016

Nuckolls J (1993) The semantics of certainty in quechua and its implications for a cultural epistemology. Language in Society; 22 (2): 235-255.

Sandova J (2010) Speaker's involvement in political interviews. MA thesis, Masarykova University: Brno, Czech Republic.

Schegloff E (1972) Notes on a Conversational Practice: Formulating Place. In: Sudnow N (ed). Studies in Social Interaction. Free Press: New York, pp 75-119.

Schiffrin D (1987) Discourse Markers. Cambridge University Press: Cambridge, UK.
Schourup L (1999) Discourse markers: tutorial overview. Lingua; 107 (3-4): 227-265.

Simon-Vandenbergen A (1988) What really really means in casual conversation and in political interviews. Linguistica Antverpiensia; 22, 206-225.

Simon-Vandenbergen A (1992) The interactional utility of of course in spoken discourse. Occasional Papers in Systemic Linguistics; 6, 213-226.

Simon-Vandenbergen A, White PRR and Aijmer K (2007) Presupposition and 'taking-for-granted' in mass communicated political argument: An illustration from British, Flemish and Swedish political colloquy. In: Fetzer A and Lauerbach GE (eds). Political discourse in the media. John Benjamins: Amsterdam, The Netherlands, pp 31-75.

Sperber S and Wilson D (2002) Pragmatics, modularity and mindreading. Mind \& Language; 17, 3-23.

Stenström A (1990) Lexical items peculiar to spoken discourse. In: Svartvik J (ed). The London-Lund Corpus of Spoken English: description and research. Lund University Press: Lund, Sweden, pp 137-175.

Stubbe M and Holmes J (1995) You know, eh and other exasperating expressions: An analysis of social and stylistic variation in the use of pragmatic devices in a sample of New Zealand English. Language and Communication; 15 (1): 63-88.

Stubbs M (1996) Text and Corpus Analysis. Blackwell: Oxford.

Swales JM (1990) Genre analysis: English in academic and research settings. Cambridge University Press: Cambridge, UK.

Tranchese A and Zollo SA (2013) The construction of gender-based violence in the british printed and broadcast media. Critical Approaches to Discourse Analysis across Disciplines; 7 (1): 141-163.

van Dijk TA (1993) Principles of critical discourse analysis. Discourse and Society; 4 (2): $249-283$

van Dijk TA (2008) Discourse and Power. Palgrave Macmillan: New York.

van Leeuwen T (1996) The representation of social actors. In: Caldas-Coulthard CR and Coulthard M (eds). Texts and Practices. Readings in Critical Discourse Analysis. Routledge: London, pp 32-69.

Wilson J (1993) Discourse marking and accounts of violence in Northern Ireland. Text; 13 (3): 455-475.

Wilson J (2001) Political discourse. In: Schiffrin D, Tannen D and Hamilton HE (eds). The Handbook of Discourse Analysis. Blackwell: Malden, MA, pp 398-414.

Wodak R (1989) Language, Power and Ideology. John Benjamins: Amsterdam, The Netherlands/Philadelphia, PA.

Wodak R (2007) Pragmatics and critical discourse analysis. A cross-theoretical inquiry. Pragmatics and Cognition; 15 (1): 203-234.

Wodak R (2009) The Discourse of Politics in Action: Politics as Usual. Palgrave Macmillan: New York.

Wodak R and Meyer M (2009) Critical discourse analysis: History, agenda, theory, and methodology. In: Wodak R and Meyer M (eds). Methods for Critical Discourse Analysis. Sage: London, pp 1-33.

Zovko I (2012) Contrastive Analysis of Discourse Markers in the Interviews with Presidents of Bosnia and Herzegovina and the U.S.A. 2nd International Conference on Foreign Language Teaching and Applied Linguistics (FLTAL'12). Sarajevo.

\section{Data availability}

The datasets analysed in the current study were derived from the following public domain resources: http://www.bbc.co.uk; http://www.cnn.com; and http://www.atv.hu.

\section{Additional information}

Competing interests: The author declares that there are no competing interests

Reprints and permission information is available at http://www.palgrave-journals.com/ pal/authors/rights_and_permissions.html

How to cite this article: Furko P (2017) Manipulative uses of pragmatic markers in political discourse. Palgrave Communications. 3:17054 doi: 10.1057/palcomms.2017.54.

Publisher's note: Springer Nature remains neutral with regard to jurisdictional claims in published maps and institutional affiliations.

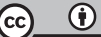

This work is licensed under a Creative Commons Attribution 4.0 International License. The images or other third party material in this article are included in the article's Creative Commons license, unless indicated otherwise in the credit line; if the material is not included under the Creative Commons license, users will need to obtain permission from the license holder to reproduce the material. To view a copy of this license, visit http://creativecommons.org/licenses/by/4.0/

C The Author(s) 2017 